DOI: $10.14746 /$ pi.2021.14.10

\title{
Ściana Płaczu: Władysław Broniewski i Jerzy Ficowski. Interpretacja porównawcza: egzemplifikacja
}

The Wailing Wall: Władysław Broniewski and Jerzy Ficowski. The comparative interpretation: exemplification

\author{
|Katarzyna Kuczyńska-Koschany \\ Uniwersytet im. Adama Mickiewicza w Poznaniu \\ IORCID: 0000-0002-1671-2278
}

\begin{abstract}
The article reminded about the rudiments that rule the comparative interpretation. The authoress refers to previous methodological and methodical arrangements, especially Bożena Chrząstowska's, and uses the adopted rudiments in practice (expanding the area with theme and topic). The sketch is an attempt of comparative interpretation of two poems written by polish poets, Władysław Broniewski (1897-1962) and Jerzy Ficowski (1924-2006) - which are about Jerusalem Wailing Wall.

Key words: comparative interpretation, interpretational hypothesis, interpretational dominant, the axis of the interpretation, Władysław Broniewski, Jerzy Ficowski, The Wailing Wall, theme, topic, the great metaphor

Streszczenie: $W$ artykule przypomniano reguły, jakimi rządzi się interpretacja porównawcza. Autorka odnosi się do dotychczasowych ustaleń metodologicznych i metodycznych, przede wszystkim Bożeny Chrząstowskiej, oraz stosuje przyjęte zasady w praktyce (rozszerzając pole o temat i topos). Szkic jest próbą interpretacji porównawczej dwu wierszy polskich poetów - Władysława Broniewskiego (1897-1962) i Jerzego Ficowskiego (1924-2006) - na temat jerozolimskiej Ściany Płaczu.

Słowa kluczowe: interpretacja porównawcza, hipoteza interpretacyjna, dominanta interpretacyjna, oś interpretacji, Władysław Broniewski, Jerzy Ficowski, Ściana Płaczu, temat, topos, wielka metafora
\end{abstract}

Pamięci Profesor Bożeny Chrząstowskiej - Nauczycielki i Osoby darzacej przyjaźnia

\section{Dwaj poeci - dwa pokolenia}

Władysław Broniewski (1897-1962) i Jerzy Ficowski (1924-2006) należą do dwu polskich pokoleń poetyckich, doświadczonych wojną. Broniewski 
- do generacji skamandrytów, czyli urodzonych na przełomie XIX i XX wieku, a potem - jak to doskonale sformułował Julian Tuwim - wziętych „w dwie wojny jak w dwa ognie". Ficowski - właściwie do pokolenia Kolumbów. Przyjrzyjmy się bliżej tym nietuzinkowym poetom.

Władysław Broniewski urodził się 17 grudnia 1897 roku w Płocku, zmarł 10 lutego $1962 \mathrm{w}$ Warszawie. Pochodził z inteligenckiej rodziny o tradycjach patriotycznych. Był poetą, tłumaczem, eseistą, diarystą, a także, co niewątpliwie wpływało na jego sposób pisania, rewolucjonistą, więźniem stalinowskim, żołnierzem na frontach I i II wojny światowej, a także wojny 1920 roku. Pisała o nim Maria Janion:

Stan służby Broniewskiego jest imponujący. Związany z drużynami strzeleckimi (pseud. Orlik), jako siedemnastoletni chłopiec porzucił klasę gimnazjalną, by wstąpić do Legionów Piłsudskiego; w ich szeregach walczył przez dwa lata. U schyłku roku 1918 znów porwał się do czynu zbrojnego, wrócił do wojska, opuszczając rozpoczęte studia uniwersyteckie. Będąc oficerem 1 Pułku Piechoty Legionów, wziął udział w wojnie polsko-bolszewickiej. W roku 1921 w stopniu kapitana, odznaczony Krzyżem Virtuti Militari, czterokrotnie Krzyżem Walecznych, przeniósł się do rezerwy, z której w roku 1939 znów na ochotnika poszedł do wojska (Janion 2007, 267).

Dalej jest szlak bojowy II wojny światowej: w poszukiwaniu jednostki przemierzył na rowerze trasę Warszawa-Lublin-Lwów-Tarnopol i 12 września trafił do Zbaraża; po inwazji radzieckiej - we Lwowie, aresztowany przez NKWD 24 stycznia 1940, przebywał w więzieniach na Zamarstynowie (Lwów), na Łubiance (Moskwa) i w Saratowie - do sierpnia 1941. Miał zaoczny wyrok pięciu lat zesłania w Kazachstanie; zwolniony znalazł się w Moskwie. W kwietniu 1942 wstąpił do Armii Polskiej w ZSRR (6. Dywizja Piechoty); w sierpniu 1942 - ewakuowany na Bliski Wschód; wziął długoterminowy urlop (od lutego 1943) i pracował w Polskim Centrum Informacji w Jerozolimie oraz w piśmie „W drodze”. Z Londynu w 1945 wrócił do Polski (Łódź, potem Warszawa). Trzykrotnie żonaty: z Janiną Kunig (1926, rozwód: 1937), z Marią Zarębińską (nieformalnie, od 1938, zm. 1947), z Wandą Burawską (1948). W 1963 roku w warszawskim domu poety utworzono Muzeum Broniewskiego; w Płocku stanął w 1972 roku jego pomnik.

Jerzy Ficowski to wybitny, zbyt rzadko czytany poeta, także dziecięcy, autor tekstów piosenek (Woziwoda, Jada wozy kolorowe) eseista, prozaik, tłumacz, znawca kultury romskiej (na przełomie lat 40. i 50. wędrował z polskimi Cyganami, odkrył poetkę Papuszę) oraz twórczości Brunona Schulza, malarstwa Witolda Wojtkiewicza i Tadeusza Makowskiego. Ficowski urodził się 4 września 1924 w Warszawie; w czasie okupacji hitlerowskiej przebywał głównie w stolicy i kontynuował na tajnych kompletach naukę, rozpoczętą w Gimnazjum im. Jana Zamoyskiego. Żołnierz Armii Krajowej, więzień Pawiaka. Podczas powstania warszawskiego walczył na Mokotowie (wzięty do niewoli, przebywał w obozach jenieckich na terenie Rzeszy, skąd powrócił w roku 1945), odznaczony Krzyżem Walecznych. Po wojnie studiował filozofię i socjologię na Uniwersytecie Warszawskim. Debiutował 
w czasopiśmie „Dziś i Jutro” (1946, nr 16) wierszem o Staffowskim tytule Ptakom niebieskim, pisał jednak już wcześniej (rękopisy wstrząsających wierszy z lat 1943-1948, cykl Siedem wierszy, wiersze $W$ byłym getcie, Jehowa, tom Uśmiech $w$ oratorium przechowuje Biblioteka Krasińskich w Warszawie). Debiutancki tom wierszy pt. Ołowiani żołnierze opublikował w roku 1948. Dwukrotnie żonaty (Wanda Komala, 1950; Elżbieta Bussold, ocalała z getta warszawskiego, 1968), ojciec trzech córek: Krystyny, Magdaleny, Anny. Członek Polskiego PEN Clubu, ZZLP, potem ZLP, a od 1989 - Stowarzyszenia Pisarzy Polskich, sygnatariusz „Memoriału 59” (1975, przeciw zmianom w Konstytucji PRL), objęty zakazem druku (19761980), członek Komitetu Obrony Robotników. Wśród wielu nagród, jakie otrzymał za swoją twórczość, warto wskazać na izraelską nagrodę literacką „Kacetnika” (za twórczość związaną z Zagładą Żydów, 1986). Zmarł 9 maja 2006, pochowany na Powązkach w Warszawie ${ }^{1}$.

\section{Czytanie porównawcze a topika i tematologia - dwa wiersze}

Obydwa wiersze dotyczą tego samego miejsca - Ściany Płaczu w Jerozolimie. Można zatem osią porównania uczynić miejsce. To, po pierwsze, istniejące realnie, najświętsze miejsce Żydów (przechowywano tam Arkę Przymierza) - jedyną pozostałość po Drugiej Świątyni Jerozolimskiej (zburzonej przez Rzymian pod wodzą Tytusa w roku 70. n.e.), zwana też Murem Zachodnim. Pobożni Żydzi wierzą, że po przyjściu Mesjasza Świątynia Jerozolimska zostanie odbudowana (Bergman 2003, 677-678). A także, po drugie, topos (Abramowska 1982, 3-23; Curtius 1997) kultury judejskiej i śródziemnomorskiej. Wreszcie, po trzecie, wielka metafora (Gasset 1996, 144-163) tradycji europejskiej.

Polscy poeci odwołując się zarówno do topiki, jak i do metaforyki, odnoszą się także do miejsca realnego. Przyjrzyjmy się obydwu wierszom. Ten autorstwa Broniewskiego został opublikowany w Jerozolimie, w „Gazecie Polskiej", w numerze 56 z 1943 roku, a potem w tomie poety-żołnierza pt. Bagnet na broń (1943):

\footnotetext{
Kilka starych kamieni

i płacz - przez tysiące lat...

Gdybym mógł to zamienić

na Wierzbową i Nowy Świat,

szedłbym z Ziemiańskiej do Ipsu

płacząc rzewnymi łzami,

a we mnie Apokalipsą,

babilońskimi rzekami
}

\footnotetext{
${ }^{1}$ Kreśląc losy poetów - Broniewskiego i Ficowskiego - wykorzystałam biogramy stworzone przeze mnie na potrzeby haseł w leksykonie literatury Zagłady. Por. Katarzyna Kuczyńska-Koschany, [Hasła] 'A Reading of Ashes' (Odczytanie popiołów), Władysław Broniewski, Selected Poetry (Poezje wybrane), w: Handbook of Polish, Czech, and Slovak Holocaust Fiction. Works and Contexts, 2021, edited by Elisa-Maria Hiemer, Jiř́i Holý, Agata Firlej, Hana Nichtburgerová, Berlin / Boston, s. 350353, 365-368.
} 
łkałoby i szlochało

Jeremiaszową pieśnią

serce, to znaczy: chaos,

warszawskie serce po Wrześniu.

Ten wiersz, który krwawi i szydzi,

te słowa już nic nie znaczą:

przyszedłem tu płakać, Żydzi

pod Ścianą Płaczu (Broniewski 2014, 294-295).

Broniewski dokonuje niejako odwrócenia toposu, wykorzystuje go na wspak: pod Ścianą Płaczu w Jerozolimie opłakuje okupowaną Warszawę (Wrzesień - pisany wielką literą - to, oczywiście, płacz po klęsce wrześniowej '39 roku), a trzy z czterech strof to jedno zdanie - długie jak szloch. Poeta (wydaje się rzeczą naturalną utożsamiać ja liryczne - (auto)biograficznie - z samym Broniewskim, skoro szedł szlakiem bojowym z Armią Andersa i przebywał w Jerozolimie w 1943 roku) ${ }^{2}$ chroni się jednak równocześnie w cieniu Ściany Płaczu, w owym „płaczu - przez tysiące lat...”, płaczu niejako starszym, większym. Wiersz staje się modlitewną prośbą o możliwość łkania (płaczu serca, co ważne) nad nieszczęściem własnej ojczyzny w tym miejscu, które stało się miejscem już nie tylko żydowskim, lecz miejscem wielkiego lamentu wszelkich pokonanych, podbitych, okupowanych. Wiersz kipi od emocji: „krwawi i szydzi”, płacze, marzy, chce zamienić Jerozolimę - miejsce najświętsze dla Europejczyka (obok Rzymu i Aten - kolebkę tożsamości) - na Warszawę, tę, którą pamięta sprzed klęski wrześniowej. Wypowiada zatem - wierszem - swego rodzaju modlitwę proszalną heretyka: miejsce, za którym tęskni, na całym świecie, prześladowany Żyd - dla pozbawionego ojczyzny i jej stolicy Polaka jest, tylko i aż, przystankiem w drodze.

Drugi z poetów, Jerzy Ficowski, wydał wiersz pt. Ściana płaczu ${ }^{3}$ w Odczytaniu popiołów (1979) - tomie poetyckim przełomowym dla polskiego procesu przyswajania prawdy o Zagładzie Żydów. Ficowski nie unikał w tym tomie wyznań o współwinie, jaką jest obojętność bądź brak działania, a także o bezradności tych, którzy na Szoa patrzyli - wiersz inicjalny tomu rozpoczyna się słowami „nie zdołałem ocalić / ani jednego życia” ${ }^{4}$, znaleźć w nim można tak wstrząsające i nowe, gdy myśleć o sposobie pisania, rejestrze poetyckim, wiersze, jak Epitafium żywcem umarłego, 5 VIII 1942 (dedykowany pamięci Janusza Korczaka), Sześcioletnia z getta żebrząca na

\footnotetext{
${ }^{2}$ Znamy nawet, dzięki Maciejowi Tramerowi, który umieszcza w swej monografii podobiznę rękopisu Ściany Płaczu, datę dzienną powstania wiersza: 23 lutego 1943. Zob. Tramer M., 2010, Brudnopis in blanco. Rzecz o poezji Broniewskiego, Katowice, s. 217.

${ }^{3}$ Pisownia tytułu jest nieustabilizowana - od Ściany Płaczu w londyńskim wydaniu Odczytania popiołów (1979), ale tam też tylko w spisie treści, gdyż wszystkie tytuły nad wierszami zapisano wersalikami - po różne wersje w innych wydaniach, z przeważającą ilościowo Ściana płaczu. Za te informacje i błyskawiczną kwerende porównawczą dziękuję serdecznie wydawcy Jerzego Ficowskiego - Piotrowi Sommerowi (który także nie podjął się ostatecznego rozstrzygnięcia intencji autora wiersza). Na potrzeby mojej interpretacji przyjmuję więc - niestety, arbitralnie - wersję Ściana płaczu, mając w pamięci obydwie możliwości.

${ }_{4}$ Ficowski J., [inc.] nie zdołałem ocalić, w: Lewe strony widoków, 2014, Sommer P., (wybrał i oprac.) Poznań, s. 139.
} 
Smolnej w 1942 roku, Pożydowskie, (inc.) Muranów góruje (o terenie byłego getta, obecnie ludnej dzielnicy mieszkaniowej Warszawy, osiedlach pobudowanych na gruzach i na ludzkich popiołach Ficowski pisze: „Muranów góruje / na warstwach umierania / fundament wsparty o kość / piwnice w wyrwach / opróżnionych z krzyku”; i dalej: „chciałbym tylko milczeć / a milcząc kłamię // chciałbym tylko iść, a idąc depczę"). Tom Odczytanie popiołów zamyka wiersz pt. Twoje matki obie (dedykowany: Biecie, z miłością) - opowieść o ocaleniu żony poety, Elżbiety Bussold-Ficowskiej, która jako noworodek została przeszmuglowana z getta na tzw. aryjską stronę Warszawy: biologiczna, żydowska matka przekazała ją polskiej, przybranej (wygłosowa strofa brzmi: „To Twoje matki obie / nauczyły cię / tak nie dziwić się wcale / kiedy mówisz / JESTEM"; Ficowski 2014, 163 - podkr. Autora).

Zazwyczaj czyta się wiersz Ściana płaczu właśnie w odniesieniu do rodzimego tomu, tu jednak zestawiam go - tematologicznie i topicznie - z utworem Broniewskiego. Następuje wychylenie ku porównaniu - teksty Ficowskiego i Broniewskiego stają się dla siebie nawzajem kontekstami. Najpierw przytoczę drugi wiersz i przedstawię jego interpretację, a później nastąpi dłuższa dygresja o istocie interpretacji porównawczej. Oto wiersz:

przez tysiąc dziewięćset lat

rzucali szlochem

o ścianę

więc im wzniesiono

cztery ściany płaczu

i w czterech ścianach

zgładzono dokładnie

płacz wszystek

i płacz tego płaczu

i łzę dziesiątą po jankielu

do ostatniego pokolenia

łez

więc jeszcze kret

nosi żałobę

i budzi kretowiska

wyrzuty ziemi (Ficowski 2014, 140)

Cały wiersz jest oparty na grze z polską frazeologią i na aluzjach literackich: w „rzucali szlochem / o ścianę” słychać „rzucali grochem o ścianę”; w sformułowaniu „cztery ściany płaczu” - potoczne „własne cztery ściany” jako synonim domu, ale przecież także Tuwimowe "Oto dom mój: cztery ściany wiersza / W mojej pięknej ojczyźnie-polszczyźnie”5; we „łzie dziesiątej po jankielu” brzmi echo „siódmej wody po kisielu” (ale znaczenie drastycznie się zmienia, gdy pomyśleć o znaczeniu samego Jankiela w kulturze polskiej, jego randze Żyda polskiego - patrioty; tu zapisano ponadto

${ }^{5}$ Tuwim J., 1936, Zieleń. Fantazja słowotwórcza, „Wiadomości Literackie”, nr 28, s. 1.

Polonistyka. Innowacje

Numer 14, 2021 
„jankiel” małą literą - uczyniono zeń eponim i symbol jednocześnie); kret-żałobnik jest, oczywiście, z wiersza Czesława Miłosza Biedny chrześcijanin patrzy na getto - to on pozostaje strażnikiem najtrudniejszej nawet pamięci, pamięci o winach własnych, pamięci tych Polaków, którzy nie pomagali Żydom podczas Zagłady.

Może jednak, z punktu widzenia osoby piszącej interpretację porównawczą, najlepszym punktem wyjścia byłoby nie poszukiwanie różnic w poetyce obydwu czytanych tutaj wierszy (u Broniewskiego - dykcja skamandrycka czy około-skamandrycka, u Ficowskiego - szczególne lingwistyczne zapisanie pamięci kultury - po Mickiewiczu, Leśmianie, Tuwimie), lecz podobieństwo strof inicjalnych:

U Broniewskiego:

Kilka starych kamieni

i płacz - przez tysiące lat...

\section{U Ficowskiego:}

przez tysiąc dziewięćset lat

rzucali szlochem

o ścianę

Do owego odwołania do prastarej historii narodu żydowskiego, historii założycielskiej dla każdego Europejczyka i dla każdej Europejki, wrócę we właściwej interpretacji, czyli w końcowej części artykułu.

\section{Interpretacja porównawcza - czym jest?}

Odwołam się do klasycznych, a - niestety - zbyt rzadko wykorzystywanych w praktyce szkolnej, artykułów Bożeny Chrząstowskiej $O$ interpretacjach porównawczych (1980) oraz O interpretacji porównawczej - po latach (1997). Nim trafiła do arkuszy maturalnych dla wybierających bardziej zaawansowany wariant egzaminu dojrzałości z języka polskiego, interpretacja porównawcza - jako zadanie - królowała podczas kolejnych Olimpiad Literatury i Języka Polskiego ${ }^{6}$.

Bożena Chrząstowska nazywa interpretację porównawczą „sytuacją istotnie problemową" i dodaje:

Wykonanie tego zadania wymaga sprawności wysokiej klasy: przede wszystkim umiejętności samodzielnego problematyzowania podanego tematu, w tym wypadku - zestawu tekstów, dostrzeżenia podobieństw i różnic w poetyce porównywanych utworów, podporządkowania założonej problematyce interpretacyjnej techniki opisu i analizy, umiejętności wyboru właściwych kontekstów, wreszcie wartościowania (Chrząstowska [1980] 2009, 89).

Wreszcie - konkluduje: „Interpretacje porównawcze umożliwiają najpełniejszą ocenę kultury literackiej uczniów: ich inteligencji, samodzielności i wrażliwości humanistycznej" (Chrząstowska [1980] 2009, 89).

${ }^{6}$ Pisząca te słowa, w kwietniu 1989 roku, zajmowała się (jako olimpijka) w warszawskim Pałacu Staszica porównawczo dwoma wierszami. Były to Syberie Norwida i Rok 1945 Miłosza. 
By pokazać, jak wymagającą formą jest interpretacja porównawcza, prowadzi nas nestorka polskiej metodyki przez zestawienie rozprawki - jako typu pracy pisemnej, wymagającej zmysłu syntezy oraz umiejętności przekonującej argumentacji, z interpretacją pojedynczego tekstu literackiego, gdzie niezbędna będzie raczej „umiejętność obserwacji szczegółu i to - dodajmy - istotnego szczegółu z punktu widzenia hipotezy interpretacyjnej" (Chrząstowska [1980] 2009, 91). Hipoteza interpretacyjna to zdolność do trafnego wskazania na dominantę interpretacyjną wiersza, a w przypadku interpretacji porównawczej - tego, co istotnie łączy dwa teksty. Pisze Chrząstowska:

Zadaniem interpretatora jest bowiem nie tylko porównanie poetyki i wyjaśnienie sensu dwóch tekstów, ale i odkrycie zasady, na której podstawie dokonano zestawienia. Nie jest ono przypadkowe, zawsze coś łączy dwie odmienne realizacje poetyckie: temat, postawa wobec świata, klimat, poetyka itp. Toteż umiejętność sproblematyzowania podanego zestawu, określenia jego podobieństw i różnic, jest podstawowym zadaniem kandydata (Chrząstowska [1980] 2009, 91, podkr. KKK).

Zatem w interpretacji pojedynczego utworu oś interpretacji przebiega wewnątrz interpretowanego tekstu 7 , zaś w porównawczej pomiędzy, jak na podanym poniżej schemacie:

Wzór interpretacji pojedynczego tekstu

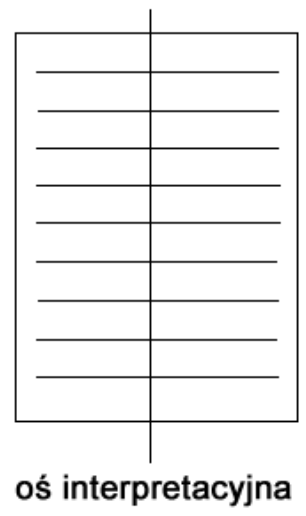

Wzór interpretacji porównawczej
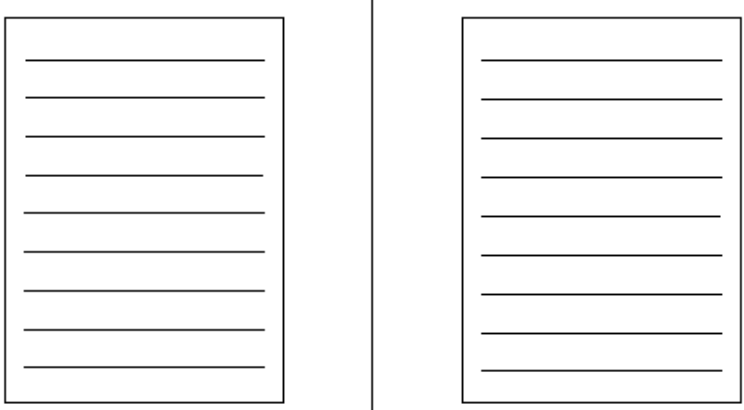

oś interpretacyjna

${ }^{7}$ Na ten temat: Chrząstowska B., Wysłouch S., 1978, Poetyka stosowana, Warszawa, s. 482-485.

Polonistyka. Innowacje

Numer 14, 2021 
Ciekawa i dająca do myślenia jest „typologia wypowiedzi interpretacyjnych", zaproponowana przez inicjatorkę i redaktorkę wielu nowatorskich podręczników szkolnych. Chrząstowska wyróżnia pięć rodzajów uczniowskiego podejścia do interpretacji porównawczej: wypowiedź eseistyczną, wypowiedź zbliżoną do krytyki literackiej, zapis lektury „rozumiejącej”, sumienną i poprawną analizę porównawczą oraz historycznoliteracką interpretację porównawczą (Chrząstowska [1980] 2009, 93). W złym wykonaniu, w swego rodzaju karykaturze tego, czego osoba oceniająca oczekiwałaby po danym typie interpretacji porównawczej:

1) eseistyka przeradza się w emocjonalne impresje,

2) krytyka literacka - w gołosłowne i bezwzględne wartościowanie,

3) zapis lektury rozumiejącej - w streszczenie przeplatane cytatami,

4) sumienna analiza - w mechaniczny i drobiazgowy opis utworu,

5) interpretacja historycznoliteracka - w „przyklejanie etykietek” (Chrząstowska [1980] 2009, 94).

Postulatem Bożeny Chrząstowskiej z roku 1997, kiedy interpretacja porównawcza pojawiła się jako jeden możliwych do wyboru tematów maturalnych i przestała już tylko ekskluzywnie dotyczyć wybranych, najzdolniejszych - czyli (najczęściej przedtem) olimpijczyków i olimpijek - pozostaje ten, nieustannie przez nią powtarzany postulat, „BLIŻEJ TEKSTU” w szkole! Autorka Przedmiotu, podmiotu i procesu pisze (wytłuszczonym przez nią samą drukiem): „nie można oczekiwać na maturze tych umiejętności, których nie kształtujemy" (Chrząstowska [1997] 2009, 121). I streszcza „potoczne sądy polonistów w tej kwestii”:

- uczniowie nie wybierają tego tematu, bo nie lubią wierszy,

- jeden utwór poetycki do analizy stanowi dopuszczalny stopień trudności,

- poezja jest zbyt trudna, by mogła służyć jako podstawa egzaminowania,

- odbiór poezji i jego pisemne świadectwa nie poddają się standaryzacji i nie sposób ustalić kryteriów oceniania takich prac,

- forma interpretacji porównawczych, jako najtrudniejsza, może funkcjonować z pożytkiem jedynie na olimpiadzie literatury (Chrząstowska [1997] 2009).

Zatem - dodam od siebie - zakładamy, iż istnieją tylko uczniowie mniej zdolni i średnio zdolni. Nie ma zdolnych i bardzo zdolnych? Jeśli coś ma istnieć poza standardem, to chyba właśnie wolne gry interpretacyjne, swobodna wypowiedź osoby wrażliwej, inteligentnej i oczytanej - oceniana przez inną osobę wrażliwą, inteligentną i oczytaną. Dlaczego nie na maturze?

\section{Jak wiersze Broniewskiego i Ficowskiego interpretować porównawczo?}

Odwołam się najpierw do własnych słów, zapisanych przy okazji współpracy z Profesor Bożeną Chrząstowską nad jednym z podręczników serii Skarbiec:

Tytuł jest naturalnym kluczem do rozumienia tekstu literackiego, rodzajem kwintesencji, czasami (...) - kontrapunktem. Analiza porównawcza tytułów 
zestawianych wierszy pozwala wypróbować własny warsztat w mikroskali, na materiale minimalnym; poza tym, i to chyba korzyść największa, pozwala sformułować wstępną hipotezę, wysłowić pierwsze, intuicyjne rozumienie, które w toku dalszych czynności interpretacyjnych powinno się "sprawdzić »: potwierdzić lub zanegować (KKK, 168).

W przypadku wierszy Broniewskiego i Ficowskiego tytuły są - na pierwszy rzut oka - identyczne. Ale diabeł - zwłaszcza w tak wymagającej niuansowania pracy myślowej jak porównanie wierszy - tkwi w szczegółach.

U Broniewskiego - Ściana Płaczu - majuskułami, z szacunku, a także oficjalnie - taki byłby też zapis w przewodniku czy w źródle historycznym (by odróżnić tę jedną jedyną na świecie Ścianę Płaczu, pozostałość Drugiej Świątyni Jerozolimskiej, od innych - funkcjonujących jako metafora lub/i eponim). To także klamra wiersza - jego ostatni wers brzmi: „pod Ścianą Płaczu”. U Ficowskiego - Ściana płaczu - sugeruje znaczenia przeniesione do świata Szoa i będzie poddawana grze słów w wierszu, którego poetyki immanentnej dominantą jest właśnie taka gra znaczeniami, frazeologizmami i aluzjami literacko-kulturowymi, byśmy - czytając - znaleźli się w świecie Zagłady Żydów. Tytuł Broniewskiego mieszka więc w Jerozolimie, a jego ja liryczne tęskni do Warszawy i Warszawę opłakuje; w tytule Ficowskiego jest już zakodowana metafora zagładowa - dlatego nie zapisuje on nazwy jerozolimskiego miejsca świętego, lecz konstruuje z ziemi, która żyła i na której żyli Żydzi polscy, „cztery ściany płaczu” - dom przemieniony w komorę gazową, w bydlęcy wagon.

„Następnym krokiem powinna być segmentacja tekstów, czyli wyodrębnienie i nazwanie cząstek znaczących w obydwu wierszach" (KKK, 169). Wiersze Broniewskiego i Ficowskiego są pod tym względem wyjątkowo interesujące, bo stroficzne. W zasadzie strofa, według wszelkich reguł poetyki, jest cząstką zamkniętą znaczeniowo i wersyfikacyjnie; jeśli przerzutnie między wersami zdarzają się w polskiej wersyfikacji dość często (stosował je już Jan Kochanowski), to przerzutnia międzystroficzna (niedomknięcie składniowe i semantyczne strofy i „dopowiedzenie” w kolejnej ${ }^{8}$ ) zdarza się sporadyczne (wręcz rzadko) i jest miejscem nacechowanym $\mathrm{w}$ wierszu. Inny jest stosunek Ficowskiego do strofiki - utrzymuje on wszelkie przerzutnie w granicach strof (czyni z nich skrytki, schowki, ziemianki, komory gazowe, bydlęce wagony, ), a inny Broniewskiego - po pierwszym zdaniu, zawartym w dwu wersach (bez przerzutni) „Kilka starych kamieni / i płacz - przez tysiące lat...", w trzecim wersie następuje złamanie strofy przerzutnią i zdanie-płacz toczy się przez kolejnych dziesięć wersów (i aż trzy strofy), lekceważąc granice stroficzne, a czasem nawet naruszając je przerzutniowo, na przykład we frazie „babilońskimi rzekami // łkałoby i szlochało". Mówiąc inaczej: Ficowski więzi płacz w innych ścianach, nie tych z murów Jerozolimy, lecz tych z czasów okupacji

\footnotetext{
${ }^{8}$ Czasem typ strofiki domaga się wręcz tego dopowiedzenia jak Dantejska tercyna, ale to nie ten przypadek, który tu analizuję.
} 
hitlerowskiej i Zagłady Żydów w Polsce, umieszcza go w przestrzeniach śmiercionośnych; Broniewski uwalnia płacz - pozwala mu spod jerozolimskiej Ściany Płaczu pofrunąć do Warszawy, rymuje „Ipsu” z „Apokalipsą”, „Jeremiaszową pieśnią” z „serce po Wrześniu”, miesza geografię rzeczywistą z geografią imaginacyjną własnego serca (Ściana Płaczu i Jerozolima z Wierzbową, Nowym Światem i Ziemiańską), topikę biblijną (Apokalipsa, Jeremiasz, rzeki Babilonu) z polską (Wrzesień).

$\mathrm{Z}$ dwu tak różnych segmentacji omawianych wierszy wynika wprost sugestia znaczeniowa: Ficowski napisał wiersz żałobny, tren po zamordowanych Żydach polskich; Broniewski - rozpaczą i bezradnością naruszając tabu miejsca („Ten wiersz, który krwawi i szydzi, /te słowa już nic nie znaczą:/przyszedłem tu płakać, Żydzi / pod Ścianą Płaczu" ) - szuka azylu tam, gdzie go rzucił żołnierski i wojenny los. Wiersz Broniewskiego ma budowę zamkniętą, schronienie może być także błędnym kołem. Wiersz Ficowskiego - otwartą, kończy się nakazem pamięci czy wręcz skandalem pamięci (tak można czytać postać kreta, który „budzi kretowiska / wyrzuty ziemi”).

U Ficowskiego nadmiar płaczu nie da się wypłakać - stąd jego hipertrofia $\mathrm{w}$ jednej ze strof. Nie istnieje nigdy zbyt wiele płaczu po zagładzie całego narodu. Nie unosi go jedna ściana płaczu, trzeba w wierszu zbudować (i ocalić) ich więcej.

U Broniewskiego - nie ma znaczeń niemożliwych dla tęsknoty. Jak Tuwimowi w Brazylii przyśniły się kwiaty polskie (i z tego marzenia wziął się najpiękniejszy może poemat w polskiej literaturze), tak autorowi Drzewa rozpaczającego uroiły się ulice i kawiarnie warszawskie, gdy płakał pod Ścianą Płaczu w Jerozolimie...

\section{Bibliografia:}

Abramowska Janina, 1982, Topos i niektóre miejsca wspólne badań literackich, „Pamiętnik Literacki”, nr 1-2, s. 3-23.

Bergman Eleonora, 2003, [hasło] Światynia Jerozolimska, w: Polski słownik judaistyczny. Dzieje. Kultura. Religia. Ludzie, t. 2, Borzymińska Z., Żebrowski R. (red.), Warszawa, s. 677-678.

Broniewski Władysław, 2014, Ściana Płaczu, w: Wybór wierszy, Bujnicki T. (wstęp i oprac.), BN I 322, Wrocław, s. 294-295.

Chrząstowska Bożena, [1980] 2009, O interpretacjach porównawczych, w: Przedmiot, podmiot i proces. Szkice z metodyki kształcenia polonistycznego, Kwiatkowska-Ratajczak M., Wantuch W. (wybór i oprac.), Poznań, s. $89-114$.

Chrząstowska Bożena, [1997] 2009, O interpretacji porównawczej - po latach, w: Przedmiot, podmiot i proces. Szkice z metodyki kształcenia polonistycznego, Kwiatkowska-Ratajczak M., Wantuch W. (wybór i oprac.), Poznań, s. $115-121$.

Chrząstowska Bożena, Wysłouch Seweryna, 1978, Poetyka stosowana, Warszawa. 
Curtius Robert Ernst, 1997, Literatura europejska i łacińskie średniowiecze, Borowski A. (przeł. i oprac.), Kraków.

Ficowski Jerzy, 2014, Lewe strony widoków, Sommer P. (wybrał i oprac.), Poznań.

Ficowski Jerzy, 1979, Odczytanie popiołów, Londyn.

Gasset José Ortega y, 1996, Dwie wielkie metafory ( $W$ dwusetna rocznice urodzin Kanta), w: Dehumanizacja sztuki i inne eseje, Niklewicz P. (przeł.), Warszawa, s. 144-163.

Janion Maria, 2007, „W starych szmatach żołnierskich”, w: Płacz generała. Eseje o wojnie [wyd. II, poszerzone], Warszawa, s. 267-275.

Kuczyńska-Koschany Katarzyna, 2004, W drodze. Wzór interpretacji porównawczej, w: Staropolskie korzenie współczesności. Podręcznik do klasy III liceum ogólnokształcacego i profilowanego. Zakres podstawowy i rozszerzony, Poznań, s. 166-171 [z serii: Skarbiec języka, literatury, sztuki, Chrząstowska B. (red.)].

Kuczyńska-Koschany Katarzyna, 2021, [Hasła] 'A Reading of Ashes' (Odczytanie popiołów), Władysław Broniewski, Selected Poetry (Poezje wybrane), w: Handbook of Polish, Czech, and Slovak Holocaust Fiction. Works and Contexts, edited by Elisa-Maria Hiemer, Jiří Holý, Agata Firlej, Hana Nichtburgerová, Berlin / Boston, s. 350-353, 365-368.

Tramer Maciej, 2010, Brudnopis in blanco, Rzecz o poezji Broniewskiego, Katowice.

\section{O Autorce:}

Katarzyna Kuczyńska-Koschany - profesor tytularna, polonistka, komparatystka, eseistka, autorka wierszy, prozy poetyckiej i autobiograficznej. Zajmuje się interpretacją poezji, recepcją poetycką w Polsce (Rilke, Rimbaud), Zagładą Żydów, synapsami poezji i plastyki, europejskim i polskim esejem literackim, polską poezją dziecięcą. Autorka książek: Rilke poetów polskich (2004; wyd. II, 2017), Rycerz i Śmierć. O „Elegiach duinejskich" Rainera Marii Rilkego (2010; wyd. II, 2015), Interlinie w ciemności. Jednak interpretacja (2012), „Все поэты жиды”. Antytotalitarne gesty poetyckie i kreacyjne wobec Zagłady oraz innych doświadczeń granicznych (2013), Skąd się bierze lekcja polskiego? Scenariusze, pomysły, konteksty (2016), Nikt nie widzi dobrze. Eseje (2018), Tuwim. Pęknięcie (2021). Opublikowała tom prozy poetyckiej Zielony promień (2006). Edytorka wierszy Anny Pogonowskiej (2018) oraz Ireny Tuwim (2020). Współautorka podręcznika licealnego Staropolskie korzenie współczesności (2004), wyróżnionego przez PAU. Opiekunka Koła Miłośników Kultury i Literatury Żydowskiej „Dabru emet” (UAM), członkini Komitetu Nauk o Literaturze PAN, Otwartej Rzeczpospolitej, Polskiego PEN Clubu. 
